\title{
Evaluation of Endogenous Sugars, Chlorogenic Acid and Caffeine Associated with Direct Somatic Embryogenesis of Coffee (Coffea arabica L.)
}

\author{
Mayoli, R.N. ${ }^{1,2}$, Isutsa, D.K. ${ }^{2,3}$, Nyende, A.B. ${ }^{4}$ and Mweu, C.M. ${ }^{4}$ \\ ${ }^{1}$ KALRO-Coffee Research Institute, P. O. Box 4-00232, Ruiru, Kenya \\ Email: rosemayoli@yahoo.com \\ ${ }^{2}$ Chuka University, P. O. Box 109-60400, Chuka, Kenya, ${ }^{3}$ Egerton University, P. O. Box 536-20115, Egerton, \\ Kenya \\ Email: dorcaski@yahoo.com \\ ${ }^{4}$ Jomo Kenyatta University of Agriculture and Technology, P. O. Box 62000-00200, Nairobi, Kenya
}

\begin{abstract}
Coffee is one of the most important cash crops cultivated in the world with great economic importance. During the induction of somatic embryogenesis, there are different endogenous compounds involved in the success or failure of the somatic embryogenesis response and these compounds determine the specificity of cellular responses. This present experiment identified and quantified endogenous sugars, chlorogenic acid and caffeine present during somatic embryogenesis of 'Ruiru 11 '. Laboratory experiments were set up at Coffee Research Institute, Ruiru-Kenya between 2014 and 2016. Third leaf pair explants were excised from 8-monthold greenhouse-grown mother plants and cultured in half strength Murashige and Skoog basal salts augmented with Thidiazuron. Once embryos had developed, the cultures were analysed for endogenous sugars, caffeine and chlorogenic acid using HPLC. Generally, green embryogenic cultures contained more and higher quantities of the compounds. Glucose and fructose were highest $(38.95 \mathrm{mg} / \mathrm{g}$ and $45.43 \mathrm{mg} / \mathrm{g}$ respectively) in leaf discs of brown non-embryogenic cultures. Sucrose was highest $(62.15 \mathrm{mg} / \mathrm{g})$ in embryos of green embryogenic cultures. Embryos of green embryogenic cultures had the highest chlorogenic acid (5.3 $\mathrm{mg} / \mathrm{g})$, whereas caffeine was highest $(0.55 \mathrm{mg} / \mathrm{g})$ in embryos of brown embryogenic cultures. Endogenous fructose and glucose inhibited embryogenesis, while sucrose, chlorogenic acids and caffeine promoted embryogenesis and are potential biomarkers for embryogenesis. Other biochemical compounds such as organic acids should be identified and their role in coffee somatic embryogenesis determined.
\end{abstract}

Keywords: Coffee, Endogenous biochemical compounds, Somatic embryogenesis, Tissue culture

Date of Publication: 30.5 .2018

DOI: $10.24297 /$ jaa.v8i1.7376

ISSN: 2349-0837

Volume: 8 Issue: 01

Journal: Journal Of Advances In Agriculture

Website: https://cirworld.com

This work is licensed under a Creative Commons Attribution 4.0 International License.

\section{Academic Discipline and Subdiscipline}

Horticulture

\section{Subject Classification}

Plant Biotechnology

\section{Type}

Tissue culture 


\section{INTRODUCTION}

There are different factors involved in the success or failure of the Somatic Embryogenesis (SE) response. One factor that affects the SE response is the release of organic molecules by the explants into the culture medium and these molecules induce or modulate the SE response (Nic-Can et al., 2015) have been classified as polysaccharides, amino acids, growth regulators, vitamins (Matthys-Rochon, 2005). In general, somatic embryos have high levels of starch, protein, and soluble carbohydrates producing excellent growth and more vigorous plants (Attree et al., 1992). The accumulation of reserves is vital for the development of somatic embryos and their conversion into plantlets (Flinn et al., 1993). Carbohydrates are energy sources for cells, carbon frameworks for biosynthetic processes and osmotic agents (Tremblay and Tremblay, 1991). Soluble sugars, such as glucose and sucrose, are involved in regulation of developmental processes occurring from embryo development to seed maturation (Gibson, 2005). In tissue culture studies, phenolic substances, especially oxidized phenolics generally affect in vitro proliferation negatively (Arnaldos et al., 2001). Phenolics are normally viewed as deleterious compounds during in vitro culture, since their exudation and oxidation negatively affect explants by causing browning and necrosis, especially when mature explants of woody plants are used. In contrast, Mucciarelli et al. (2000) suggested that many phenolic compounds control auxin catabolism probably by raising or lowering the level of indole acetic acid (IAA) through enzymatic reactions to permit embryo formation. Alkaloid accumulation observed during production of secondary plant metabolites is attributed to the level of the alkaloid biosynthesis and is strongly influenced by cellular differentiation (Ivanov et al., 2012). This paper reports glucose, fructose, sucrose, chlorogenic acid and caffeine identified, quantified and analysed during development of coffee somatic embryos in vitro.

\section{MATERIALS AND METHODS}

The experiment was conducted in the laboratories and greenhouses of the Coffee Research Institute at Ruiru in Kenya. The site is situated $1.05^{\circ} \mathrm{S}$ and $36.45^{\circ} \mathrm{E}$ at an elevation of $1608 \mathrm{~m}$ above the sea level and has humic nitosol soils (Jaetzold et al., 2007). The Coffea arabica cultivar Ruiru 11 planted at this site was used in the experiment. The plants were moved from the fields to laboratories and then to greenhouses.

\subsection{Plant material, surface sterilization and induction of somatic embryos}

The mother plants for this experiment were obtained from germination of Ruiru 11 seeds. The resulting seedlings were transplanted to polybags filled with top soil: sand: manure $(3: 2: 1 \mathrm{v} / \mathrm{v})$ potting mixture and maintained in the greenhouse for about 8 months.

Third leaf pair explants were excised from the greenhouse-grown mother plants between March and April, 2014. The leaves were washed thoroughly under running tap water followed by water containing Teepol detergent and finally sterile distilled water. The subsequent sterilization steps were done in a laminar flow cabinet. The leaves were dipped quickly (approximately 30 seconds) in $70 \%$ alcohol and rinsed $2-3$ times in sterilized distilled water. The leaves were sterilized further using $25 \%$ sodium hypochlorite for 25 minutes followed by rinsing thoroughly (4 times) in sterilized distilled water. The culture medium contained halfstrength Murashige and Skoog (MS 1962) inorganic basal salts, supplemented with $0.2 \mathrm{~g} / \mathrm{L}$ thiamine, $0.1 \mathrm{~g} / \mathrm{L}$ nicotinic acid, $0.1 \mathrm{~g} / \mathrm{L}$ pyridoxine, $30 \mathrm{~g} / \mathrm{L}$ sucrose, $100 \mathrm{mg} / \mathrm{L}$ myo-inositol, $100 \mathrm{mg} / \mathrm{L}$ cysteine, $3 \mathrm{~g} / \mathrm{L}$ gelrite, and $1 \mathrm{ml} / \mathrm{L}$ Thidiazuron. The $\mathrm{pH}$ of the medium was adjusted to 5.7 using $1 \mathrm{M} \mathrm{NaOH}$ or $1 \mathrm{M} \mathrm{HCl}$ and $3 \mathrm{~g} / \mathrm{L} \mathrm{gelrite}$ added before autoclaving for 15 minutes at $121^{\circ} \mathrm{C}$ and $100 \mathrm{kPa}$. Culture medium $(25 \mathrm{ml})$ was poured into Magenta vessels (Sigma Chemical Co.) and 5 leaf discs $\left(1 \mathrm{~cm}^{2}\right)$ cultured in each vessel maintained in a dark, 25 $\pm 2^{\circ} \mathrm{C}$ and $70 \%$ relative humidity growth chamber for about 8 months. A total of 627 culture vessels were prepared. Out of these 627 vessels, 183 (29\%) were discarded due to fungal contamination.

\subsection{Treatments}

From the remaining 444 culture vessels, treatments for this experiment were selected. Culture vessels with green and brown leaf discs with and without embryos as shown in Plate 1 were used to characterise glucose, fructose, sucrose, chlorogenic acid, and caffeine in the leaf discs, embryos and medium. Fresh culture media and leaf explants excised from greenhouse-grown mother plants were used as the controls. The experimental 
layout was a completely randomized design, with three replications and six culture vessels per treatment. The experiment was repeated once.
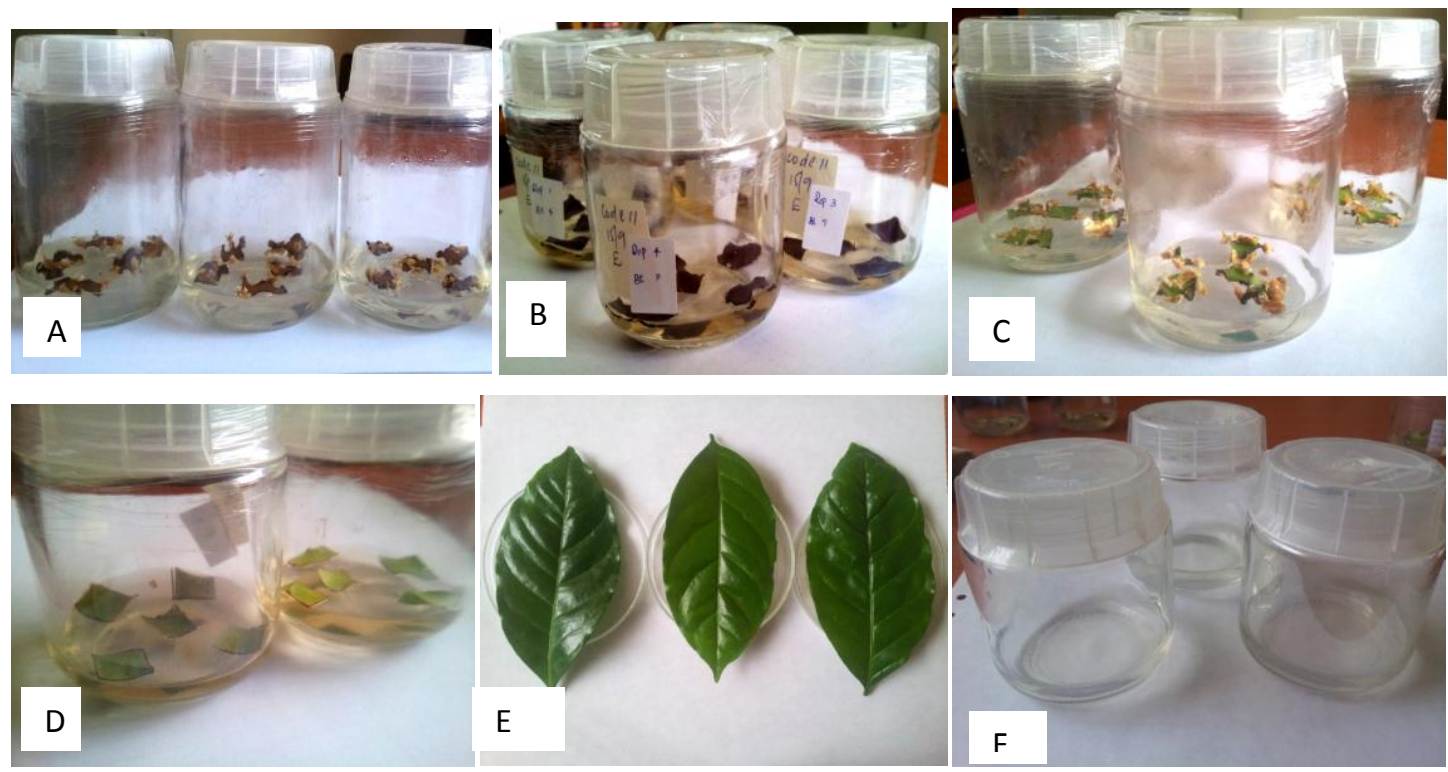

Plate 1: Treatments used for biochemical analysis. A: Brown leaf discs with embryos. B: brown leaf discs without embryos. C: green leaf discs with embryos. D: Green leaf discs without embryos, E: Fresh leaves (control). F: Fresh media (control)

\subsection{Extraction and evaluation of sugars}

The sugars sucrose, fructose and glucose were extracted as described by Osborne and Voogt (1978) with modifications. The leaf discs, somatic embryos and culture medium from culture vessels with green and brown leaf discs, with and without embryos were separately weighed and placed into round bottomed flasks. About $100 \mathrm{ml}$ of $96 \%$ ethanol was added into each flask. The extraction of the sugars was done for one hour under reflux by boiling the leaf discs, somatic embryos, or media with the ethanol, while continually cooling of the vapour to liquid and returning it back to the flasks for 25 minutes and leaving the contents to cool. The extract was filtered and evaporated to dry. The extract was reconstituted to $2 \mathrm{ml}$ for the leaf and $5 \mathrm{ml}$ for the embryo and media using mobile phase acetonitrile: distilled water at a ratio of 80:20. The extract sample was filtered through a $0.45 \mu \mathrm{m}$ micro-filter (Chromafil) and analyzed with High Performance Liquid Chromatography (HPLC).

\subsection{Extraction and evaluation of chlorogenic acid}

Extraction of chlorogenic acid was done as described by Kathurima and Njoroge (2012). Leaf discs $\left(1 \mathrm{~cm}^{2}\right)$, somatic embryos and culture medium from culture vessels with green and brown leaf discs, with and without embryos were weighed into $100 \mathrm{ml}$ conical flasks and the weights recorded. About $50 \mathrm{ml}$ of $96 \%$ ethanol (AR) and $10 \mathrm{ml}$ acetone were added to each sample. The sample was first homogenized at $4^{\circ} \mathrm{C}$ and then transonicated using an ultrasonic bath for 10 minutes. Filtering was done using Whatman No. $42(12.5 \mathrm{~cm})$ paper. The filtrate was recovered in a $100 \mathrm{ml}$ round bottomed flasks and evaporated at $40^{\circ} \mathrm{C}$. The sample was reconstituted with $2 \mathrm{ml}$ of $50 \%$ methanol, filtered through $0.45 \mu \mathrm{m}$ micro-filters and analyzed with HPLC.

\subsection{Extraction and evaluation of caffeine}

Caffeine was extracted as described by Kathurima and Njoroge (2012). Leaf discs (1 cm²), somatic embryos and culture medium from culture vessels with green and brown leaf discs, with and without embryos were weighed into $250 \mathrm{ml}$ flat-bottomed flasks with round necks. Thereafter, $0.5 \mathrm{~g}$ magnesium oxide (Merck) and $200 \mathrm{ml}$ distilled water were added into the flasks. Refluxing was done by boiling while continually cooling the vapour to liquid and returning it back to the flasks for 25 minutes and leaving the contents to cool. After cooling, filtration was done under vacuum on celite and the filtrate recovered in $250 \mathrm{ml}$ volumetric flask. The volume 
was topped up using distilled water to the mark and $20 \mathrm{ml}$ of the filtrate drawn and put into $100 \mathrm{ml}$ volumetric flask. The volume was adjusted to the mark using $20 \%$ acetonitrile. The eluate was filtered through a $0.45 \mu \mathrm{m}$ micro-filters and analyzed with HPLC.

\subsection{Data collection on the sugars}

Glucose, fructose and sucrose were analyzed by injecting about $50 \mu \mathrm{l}$ of the extract/sample into Knauer HPLC equipped with a Eurospher $100-5 \mathrm{NH}_{2}$ column and a reflective index detector. The mobile phase had $75 \%$ acetonitrile HPLC grade (SCHARLAU) and 25\% distilled water at a flow rate of $1 \mathrm{ml} /$ minute under ambient temperature. Glucose, fructose and sucrose were identified by comparing the retention time with that of sucrose standard (Fischer Scientific) and their concentration was calculated from peaks using calibration equations, where: Concentration of analyte $\left(C_{1}\right)=$ Peak of analyte/slope of the standards' calibration curve. Content $(\mathrm{mg} / \mathrm{g})$ of the analyte $=\left[C_{1} \times \vee \times 1000^{-3}\right] / \mathrm{W}$, Where $C_{1}=$ concentration $(\mathrm{mg} / \mathrm{L})$ of the analyte in the test solution, $V=$ volume $(\mathrm{mL})$ of the test solution, and $\mathrm{W}=$ weight $(\mathrm{g})$ of the sample used for preparation of the test solution.

\subsection{Data collection on chlorogenic acid and caffeine}

Caffeine and chlorogenic acid were analyzed by injecting about $50 \mu \mathrm{l}$ of eluate sample into Knauer HPLC equipped with a super Co Discovery C-18 column for caffeine and BDS HYPERSIL C-18 column for chlorogenic acid. The detector was diode array at $278 \mathrm{~nm}$ and $324 \mathrm{~nm}$ wavelengths for caffeine and chlorogenic acid respectively. The mobile phase had 35\% methanol HPLC grade (PANCREAC), $65 \%$ distilled water, and $0.1 \%$ acetic acid (PROLABO) at a flow rate of $1 \mathrm{ml} /$ minute under ambient temperature. Caffeine and chlorogenic acid were identified by comparing the retention time of caffeine standard (99\%) (Fischer Scientific) and chlorogenic acid standard (Acros Organics) with the sample peaks. The concentration was calculated from peaks using calibration equations, where: Concentration of analyte $\left(C_{1}\right)=$ Peak of analyte/slope of the standards' calibration curve. Content $(\mathrm{mg} / \mathrm{g})$ of the analyte $=\left[C_{1} \times \mathrm{V} \times 1000^{-3}\right] / \mathrm{W}$, Where $C_{1}=$ concentration $(\mathrm{mg} / \mathrm{L})$ of the analyte in the test solution, $\mathrm{V}=$ volume $(\mathrm{mL})$, of the test solution, and $\mathrm{W}=$ weight $(\mathrm{g})$ of the sample used to prepare the test solution.

\subsection{Data analysis}

The SAS 9.2 computer software was used to analyze data. Data values were subjected to analysis of variance using the General Linear Model for a completely randomized design. The linear model fitted to the CRD data was: $Y i j=\mu+T i+\varepsilon i j$, Where: $\mu$ is grand mean, $\mathrm{Ti}$ is $\mathrm{i}^{\text {th }}$ concentration of the endogenous factor; $i=1,2,3 \ldots 10$, 11,$12 ; j=1,2,3$; and $\varepsilon i j$ is random error component, normally and independently distributed about zero mean with a common variance $\sigma^{2}$. Differences between treatment means were separated using LSD test at $P=0.05$.

\section{RESULTS}

\subsection{Evaluation of endogenous sugars}

The glucose, fructose and sucrose contents obtained are shown in Table 1. There were significant differences in the glucose content of the samples on fresh weight basis (FW) and dry weight basis (DW) (Table 1). Brown leaf discs without embryos had endogenous glucose content of $38.95 \mathrm{mg} / \mathrm{g} \mathrm{FW}$ and $273.97 \mathrm{mg} / \mathrm{g}$ DW. No glucose was detected in green leaf discs without embryos. Glucose was significantly $(P<0.05)$ high in embryos developed from brown leaf discs at $2.76 \mathrm{mg} / \mathrm{g} \mathrm{FW}$ and $19.54 \mathrm{mg} / \mathrm{g} \mathrm{DW}$. There were significant differences in glucose content in the culture media. Brown leaf discs without embryos had endogenous glucose content of $13.43 \mathrm{mg} / \mathrm{g} \mathrm{FW}$, whereas the green leaf discs without embryos had endogenous glucose content of $580 \mathrm{mg} / \mathrm{g}$ DW.

Significant $(P<0.05)$ differences resulted in endogenous fructose content (Table 1$)$. Brown leaf discs without embryos had fructose content of $45.43 \mathrm{mg} / \mathrm{g} \mathrm{FW}$ and $277.55 \mathrm{mg} / \mathrm{g} \mathrm{DW}$. Embryos that had developed from brown leaf discs had the significantly $(P<0.05)$ higher fructose content of $4.14 \mathrm{mg} / \mathrm{g} \mathrm{FW}$ and $29.28 \mathrm{mg} / \mathrm{g} \mathrm{DW}$. The highest $(P<0.05)$ fructose content of $17.19 \mathrm{mg} / \mathrm{g} \mathrm{FW}$ and $620.77 \mathrm{mg} / \mathrm{g}$ DW resulted in the culture media where the leaf discs had turned brown and no embryos formed. 
Significant differences resulted in the endogenous sucrose content in the treatments tested (Table 1). Freshly harvested leaves had the highest $(P<0.05)$ sucrose content of $19.26 \mathrm{mg} / \mathrm{g} \mathrm{FW}$ and $125.67 \mathrm{mg} / \mathrm{g} \mathrm{DW}$. Embryos developed from green leaf discs had the highest $(P<0.05)$ sucrose content of $62.15 \mathrm{mg} / \mathrm{g} \mathrm{FW}$ and $512.05 \mathrm{mg} / \mathrm{g}$ DW. Sucrose content of $16.22 \mathrm{mg} / \mathrm{g} \mathrm{FW}$ and $648.82 \mathrm{mg} / \mathrm{g}$ DW was detected in control culture media.

Table 1: Glucose, fructose and sucrose contents in leaves, embryos and culture media

\begin{tabular}{|c|c|c|c|c|c|c|}
\hline Treatment & $\mathrm{FW}(\mathrm{mg} / \mathrm{g})$ & $\mathrm{DW}(\mathrm{mg} / \mathrm{g})$ & $\mathrm{FW}(\mathrm{mg} / \mathrm{g})$ & $\mathrm{DW}(\mathrm{mg} / \mathrm{g})$ & $\mathrm{FW}(\mathrm{mg} / \mathrm{g})$ & $\mathrm{DW}(\mathrm{mg} / \mathrm{g})$ \\
\hline \multicolumn{3}{|c|}{ Glucose in leaves } & \multicolumn{2}{|c|}{ Glucose in embryos } & \multicolumn{2}{|c|}{ Glucose in media } \\
\hline CM & $0.0 \pm 0.0^{\mathrm{d} *}$ & $0.0 \pm 0.0^{d}$ & $0.0 \pm 0.0^{c}$ & $0.0 \pm 0.0^{c}$ & $3.5 \pm 0.4^{c}$ & $138.2 \pm 15.6^{d}$ \\
\hline CL & $16.3 \pm 0.1^{b}$ & $106.4 \pm 1.0^{b}$ & $0.0 \pm 0.0^{c}$ & $0.0 \pm 0.0^{c}$ & $0.0 \pm 0.0^{\mathrm{e}}$ & $0.0 \pm 0.0^{\mathrm{e}}$ \\
\hline GE & $0.2 \pm 0.0^{d}$ & $1.2 \pm 0.3^{d}$ & $2.1 \pm 0.0^{b}$ & $16.9 \pm 0.3^{b}$ & $2.4 \pm 1.7^{d}$ & $178.2 \pm 13.2^{c}$ \\
\hline GW & $0.0 \pm 0.0^{d}$ & $0.0 \pm 0.0^{d}$ & $0.0 \pm 0.0^{c}$ & $0.0 \pm 0.0^{c}$ & $7.9 \pm 0.1^{b}$ & $580.4 \pm 7.1^{\mathrm{a}}$ \\
\hline $\mathrm{BE}$ & $4.0 \pm 1.8^{c}$ & $24.3 \pm 11.2^{c}$ & $2.8 \pm 0.1^{\mathrm{a}}$ & $19.6 \pm 0.7^{a}$ & $0.1 \pm 0.0^{\mathrm{e}}$ & $4.94 \pm 1.0^{\mathrm{e}}$ \\
\hline BW & $39.0 \pm 1.0^{a}$ & $274.0 \pm 6.2^{\mathrm{a}}$ & $0.0 \pm 0.0^{c}$ & $0.0 \pm 0.0^{c}$ & $13.4 \pm 0.5^{a}$ & $485.2 \pm 19.0^{\mathrm{b}}$ \\
\hline CV (\%) & 15.0 & 14.8 & 9.0 & 8.6 & 10.7 & 8.8 \\
\hline LSD (0.05) & 2.7 & 16.2 & 0.1 & 0.9 & 0.9 & 36.2 \\
\hline \multicolumn{3}{|c|}{ Fructose in leaves } & \multicolumn{2}{|c|}{ Fructose in embryos } & \multicolumn{2}{|c|}{ Fructose in media } \\
\hline CM & $0.0 \pm 0.0^{\mathrm{d} *}$ & $0.0 \pm 0.0^{d}$ & $0.0 \pm 0.0^{c}$ & $0.0 \pm 0.0^{c}$ & $3.3 \pm 0.0^{c}$ & $132.9 \pm 1.5^{c}$ \\
\hline$C L$ & $3.4 \pm 0.1^{c}$ & $22.3 \pm 0.3^{c}$ & $0.0 \pm 0.0^{c}$ & $0.0 \pm 0.0^{c}$ & $0.0 \pm 0.0^{d}$ & $0.0 \pm 0.0^{d}$ \\
\hline GE & $0.4 \pm 0.0^{d}$ & $2.2 \pm 0.2^{d}$ & $2.7 \pm 0.3^{b}$ & $22.5 \pm 2.8^{b}$ & $3.6 \pm 0.0^{c}$ & $266.9 \pm 14.2^{b}$ \\
\hline GW & $0.0 \pm 0.0^{d}$ & $0.0 \pm 0.0^{d}$ & $0.0 \pm 0.0^{c}$ & $0.0 \pm 0.0^{c}$ & $8.3 \pm 0.0^{b}$ & $610.4 \pm 6.4^{a}$ \\
\hline $\mathrm{BE}$ & $10.3 \pm 2.0^{b}$ & $62.7 \pm 12.3^{b}$ & $4.1 \pm 0.3^{a}$ & $29.3 \pm 2.1^{\mathrm{a}}$ & $0.6 \pm 0.0^{d}$ & $21.1 \pm 7.5^{d}$ \\
\hline BW & $45.4 \pm 0.8^{a}$ & $277.6 \pm 5.0^{\mathrm{a}}$ & $0.0 \pm 0.0^{c}$ & $0.0 \pm 0.0^{c}$ & $17.2 \pm 0.5^{a}$ & $620.8 \pm 19.0^{a}$ \\
\hline CV (\%) & 15.5 & 15.5 & 28.0 & 28.7 & 7.8 & 6.6 \\
\hline LSD (0.05) & 2.7 & 16.7 & 0.6 & 4.4 & 0.8 & 32.35 \\
\hline \multicolumn{3}{|c|}{ Sucrose in leaves } & \multicolumn{2}{|c|}{ Sucrose in embryos } & \multicolumn{2}{|c|}{ Sucrose in media } \\
\hline CM & $0.0 \pm 0.0^{d}$ & $0.0 \pm 0.0^{d}$ & $0.0 \pm 0.0^{c}$ & $0.0 \pm 0.0^{c}$ & $16.2 \pm 0.2^{\mathrm{a}}$ & $648.8 \pm 6.5 a$ \\
\hline $\mathrm{CL}$ & $19.2 \pm 0.3^{\mathrm{a} \star}$ & $125.7 \pm 2.2^{\mathrm{a}}$ & $0.0 \pm 0.0^{c}$ & $0.0 \pm 0.0^{c}$ & $0.0 \pm 0.0^{b}$ & $0.0 \pm 0.0^{b}$ \\
\hline GE & $11.3 \pm 0.2^{\mathrm{b}}$ & $69.3 \pm 1.3^{b}$ & $62.2 \pm 2.0^{\mathrm{a}}$ & $512.1 \pm 16.5^{\mathrm{a}}$ & $0.0 \pm 0.0^{b}$ & $0.0 \pm 0.0^{b}$ \\
\hline GW & $6.7 \pm 0.5^{c}$ & $40.7 \pm 2.9^{c}$ & $0.0 \pm 0.0^{c}$ & $0.0 \pm 0.0^{c}$ & $0.0 \pm 0.0^{b}$ & $0.0 \pm 0.0^{b}$ \\
\hline $\mathrm{BE}$ & $0.0 \pm 0.0^{d}$ & $0.0 \pm 0.0^{d}$ & $37.2 \pm 0.8^{b}$ & $263.2 \pm 6.0^{\mathrm{b}}$ & $0.0 \pm 0.0^{b}$ & $0.0 \pm 0.0^{b}$ \\
\hline BW & $0.0 \pm 0.0^{d}$ & $0.0 \pm 0.0^{d}$ & $0 c$ & $0^{c}$ & $0.0 \pm 0.0^{b}$ & $0.0 \pm 0.0^{b}$ \\
\hline CV (\%) & 7.0 & 6.9 & 9.3 & 9.6 & 4.3 & 4.3 \\
\hline LSD (0.05) & 0.8 & 4.8 & 2.7 & 22.1 & 0.2 & 8.2 \\
\hline
\end{tabular}

*Values followed by the same letter within each column are not significantly different according to the LSD test at $P=0.05$. Key: BW - Brown leaf discs without embryos, BE - Brown leaf discs with embryos, GE - Green leaf discs with embryos, GW - Green leaf discs without embryos, CL - Fresh leaves (Control), CM -Fresh media (Control).

\subsection{Evaluation of chlorogenic acid}

There were significant differences in chlorogenic acid content in the samples (Table 2). Fresh leaves had the highest $(P<0.05)$ chlorogenic acid content of $6.51 \mathrm{mg} / \mathrm{g} \mathrm{FW}$ and $42.56 \mathrm{mg} / \mathrm{g} \mathrm{DW}$. Chlorogenic acid content of $5.34 \mathrm{mg} / \mathrm{g} \mathrm{FW}$ and $44 \mathrm{mg} / \mathrm{g}$ DW was significantly $(P<0.05)$ high in embryos developed from green leaf discs. There were significant $(P<0.05)$ differences in chlorogenic acid content in the culture media. Green leaf discs with embryos had the highest amounts of chlorogenic acid content of $0.004 \mathrm{mg} / \mathrm{g} \mathrm{FW}$ and $0.34 \mathrm{mg} / \mathrm{g} \mathrm{DW}$.

Table 2: Chlorogenic acid content in leaves, embryos and media

\begin{tabular}{lllcccc}
\hline Treatment & FW $(\mathrm{mg} / \mathrm{g})$ & $\mathrm{DW}(\mathrm{mg} / \mathrm{g})$ & $\mathrm{FW}(\mathrm{mg} / \mathrm{g})$ & $\mathrm{DW}(\mathrm{mg} / \mathrm{g})$ & $\mathrm{FW}(\mathrm{mg} / \mathrm{g})$ & DW $(\mathrm{mg} / \mathrm{g})$ \\
\hline & CGA in leaves & \multicolumn{2}{c}{ CGA in embryos } & CGA in media \\
\hline $\mathrm{CM}$ & $0.0 \pm 0.0^{\mathrm{c}}$ & $0.0 \pm 0.0^{\mathrm{c}}$ & $0.0 \pm 0.0^{\mathrm{c}}$ & $0.0 \pm 0.0^{\mathrm{c}}$ & $0.0 \pm 0.0^{\mathrm{e}}$ & $0.0 \pm 0.0^{\mathrm{d}}$ \\
$\mathrm{CL}$ & $6.5 \pm 0.0^{\mathrm{a}}$ & $42.6 \pm 0.2^{\mathrm{a}}$ & $0.0 \pm 0.0^{\mathrm{c}}$ & $0.0 \pm 0.0^{\mathrm{c}}$ & $0.0 \pm 0.0^{\mathrm{e}}$ & $0.0 \pm 0.0^{\mathrm{d}}$ \\
$\mathrm{GE}$ & $1.3 \pm 0.2^{\mathrm{b}}$ & $8.2 \pm 1.4^{\mathrm{b}}$ & $5.3 \pm 0.1^{\mathrm{a}}$ & $44.0 \pm 0.7^{\mathrm{a}}$ & $0.005 \pm 0.0^{\mathrm{a}}$ & $0.3 \pm 0.0^{\mathrm{a}}$
\end{tabular}




\begin{tabular}{lllllll} 
GW & $1.4 \pm 0.2^{\mathrm{b}}$ & $8.4 \pm 1.1^{\mathrm{b}}$ & $0.0 \pm 0.0^{\mathrm{c}}$ & $0.0 \pm 0.0^{\mathrm{c}}$ & $0.002 \pm 0.0^{\mathrm{c}}$ & $0.1 \pm 0.0^{\mathrm{b}}$ \\
BE & $0.1 \pm 0.0^{\mathrm{c}}$ & $0.4 \pm 0.0^{\mathrm{c}}$ & $3.3 \pm 0.3^{\mathrm{b}}$ & $23.4 \pm 2.1^{\mathrm{b}}$ & $0.004 \pm 0.0^{\mathrm{b}}$ & $0.2 \pm 0.0^{\mathrm{b}}$ \\
BW & $0.1 \pm 0.0^{\mathrm{c}}$ & $0.4 \pm 0.0^{\mathrm{c}}$ & $0.0 \pm 0.0^{\mathrm{c}}$ & $0 \mathrm{c}$ & $0.001 \pm 0.0^{\mathrm{d}}$ & $0.04 \pm 0.0^{\mathrm{c}}$ \\
CV (\%) & 13.5 & 12.9 & 15.4 & 14.2 & 21.84 & 16.1 \\
LSD (0.05) & 0.4 & 2.3 & 0.4 & 2.8 & 0.001 & 0.03 \\
\hline
\end{tabular}

*Values followed by the same letter within each column are not significantly different according to the LSD test at $P=0.05$. Key: BW - Brown leaf discs without embryos, BE - Brown leaf discs with embryos, GE - Green leaf discs with embryos, GW - Green leaf discs without embryos, CL - Fresh leaves (Control), CM - Fresh media (Control)

\subsection{Evaluation of caffeine}

Significant $(P<0.05)$ differences resulted in endogenous caffeine content (Table 3$)$. Fresh leaves had the highest caffeine content of $1.14 \mathrm{mg} / \mathrm{g} \mathrm{FW}$ and $4.0867 \mathrm{mg} / \mathrm{g}$ DW. Embryos that had developed from brown leaf discs had significantly $(P<0.05)$ higher caffeine content of $0.58 \mathrm{mg} / \mathrm{g} \mathrm{FW}$ and $4.09 \mathrm{mg} / \mathrm{g} \mathrm{DW}$. The highest $(P<0.05)$ caffeine content of $0.69 \mathrm{mg} / \mathrm{g} \mathrm{FW}$ and $51.21 \mathrm{mg} / \mathrm{g} \mathrm{DW}$ resulted in the culture media with green leaf discs with embryos. Significant $(P<0.05)$ differences resulted in endogenous caffeine content among the leaf discs tested (Table 3). Fresh leaves had the highest caffeine content of $1.14461 \mathrm{mg} / \mathrm{g} \mathrm{FW}$. Embryos that had developed from brown leaf discs had significantly $(P<0.05)$ high caffeine content of $0.58 \mathrm{mg} / \mathrm{g} \mathrm{FW}$. The highest $(P<0.05)$ caffeine content of $0.69 \mathrm{mg} / \mathrm{g} \mathrm{FW}$ resulted in the culture media that had green leaf discs with embryos.

Table 3: Caffeine content in leaves, embryos and culture media

\begin{tabular}{|c|c|c|c|c|c|c|}
\hline Treatment & $\mathrm{FW}(\mathrm{mg} / \mathrm{g})$ & $\mathrm{DW}(\mathrm{mg} / \mathrm{g})$ & $\mathrm{FW}(\mathrm{mg} / \mathrm{g})$ & DW $(\mathrm{Mg} / \mathrm{g})$ & $\mathrm{FW}(\mathrm{mg} / \mathrm{g})$ & DW $(\mathrm{mg} / \mathrm{g})$ \\
\hline & \multicolumn{2}{|c|}{ Caffeine in leaves } & \multicolumn{2}{|c|}{ Caffeine in embryos } & \multicolumn{2}{|c|}{ Caffeine in media } \\
\hline CM & $0.0 \pm 0.0^{d}$ & $0.0 \pm 0.0^{c}$ & $0.0 \pm 0.0^{b}$ & $0.0 \pm 0.0^{b}$ & $0.00 \pm 0.0^{c}$ & $0.0 \pm 0.0^{b}$ \\
\hline$C L$ & $1.1 \pm 0.1^{\mathrm{a}}$ & $7.5 \pm 0.4^{a}$ & $0.0 \pm 0.0^{b}$ & $0.0 \pm 0.0^{b}$ & $0.00 \pm 0.0^{c}$ & $0.0 \pm 0.0^{b}$ \\
\hline GE & $0.2 \pm 0.0^{c}$ & $1.0 \pm 0.2^{b}$ & $0.0 \pm 0.0^{b}$ & $0.0 \pm 0.0^{b}$ & $0.70 \pm 0.0^{\mathrm{a}}$ & $51.2 \pm 1.7^{a}$ \\
\hline GW & $0.2 \pm 0.0^{b c}$ & $1.3 \pm 0.2^{b}$ & $0.0 \pm 0.0^{\mathrm{b}}$ & $0.0 \pm 0.0^{b}$ & $0.02 \pm 0.0^{\mathrm{bc}}$ & $1.2 \pm 0.0^{\mathrm{b}}$ \\
\hline $\mathrm{BE}$ & $0.3 \pm 0.0^{b}$ & $1.7 \pm 0.3^{b}$ & $0.6 \pm 0.0^{a}$ & $4.1 \pm 0.3 a$ & $0.04 \pm 0.0^{\mathrm{b}}$ & $1.3 \pm 0.0^{b}$ \\
\hline BW & $0.2 \pm 0.0^{b c}$ & $1.3 \pm 0.2^{\mathrm{b}}$ & $0.0 \pm 0.0^{b}$ & $0.0 \pm 0.0^{b}$ & $0.01 \pm 0.0^{\mathrm{bc}}$ & $0.5 \pm 0.0^{b}$ \\
\hline CV (\%) & 19.6 & 19.4 & 29.1 & 28.8 & 13.3 & 13.7 \\
\hline LSD (0.05) & 0.1 & 0.7 & 0.1 & 0.4 & 0.03 & 2.2 \\
\hline
\end{tabular}

*Values followed by the same letter within each column are not significantly different according to the LSD test at $P=0.05$. Key: BW - Brown leaf discs without embryos, BE - Brown leaf discs with embryos, GE - Green leaf discs with embryos, GW - Green leaf discs without embryos, CL - Fresh leaves (Control), CM - Fresh media (Control)

\section{DISCUSSION}

\subsection{Sugars}

It is generally accepted that explant browning results in a decline in culture competence, with eventual loss of totipotency or even death of explants (Benson, 2000). Explant browning is usually caused by oxidase. Polyphenol oxidase (PPO) oxidizes phenols to produce brown-coloured ubiquinols, which accumulate in explants and are released into the medium (Liu et al., 2015). However, explant browning can also be caused by environmental stress or other adverse conditions, including programmed cell death (PCD) and natural death (Liu et al., 2015). In the present experiment, brown explants also generated somatic embryos. Although the mechanisms for the PCD induction of SE are not clear, two waves of programmed cell death occurred during SE of Norway spruce, which indicated that PCD played important roles in formation and development of somatic embryos (Filonova et al., 2000). This might be the explanation for the development of somatic embryos in browned explants and non-browned explants. 
Lipavska and Konrádova (2004) suggested the negative effect of accumulation of 6 carbon sugars such as fructose and glucose in embryo cells. In plants, endogenous fructose and glucose is derived from hydrolysis of sucrose, which occurs in reactions catalyzed by enzymes $\beta$-fructofuranosidase (EC 3.2.1.26) or sucrose synthase (EC 2.4.1.13) (Sturm and Tang, 1999). Generally, higher fructose content than glucose content was present in the leaf discs and this may be attributed to the fact that plant cells would uptake the glucose preferentially which competitively inhibits the uptake of fructose. The preference of glucose than fructose by cells was caused by its ability to be catabolized directly through glycolysis, whereas fructose has to be converted into glucose and sucrose prior to glycolysis (Dijkema et al., 1988). Businge et al., (2012) reported that in Norway spruce somatic embryogenesis, non-embryogenic cell line 06:22:02 had high fructose, indicating that relatively high levels of endogenous fructose prior to maturation was associated with the subsequent aberrant embryo development.

Higher sucrose content than glucose and fructose contents in mature coffee somatic embryos were observed in the present experiment. Similar observations have been reported in somatic embryogenesis of avocado (Sanchez-Romero et al., 2002) where initially the hexose/sucrose levels were high in small embryos measuring 7-8 $\mathrm{mm}$ long, but with further development of up to $25 \mathrm{~mm}$, a switch in the hexose/sucrose ratio took place due to a decrease in hexose levels and an increase in sucrose level. The trend continued in the following developmental stages reaching the lowest hexose/sucrose ratio in embryos measuring $38-40 \mathrm{~mm}$ long (Sanchez-Romero et al., 2002). Pescador et al. (2008) also reported the amounts of glucose and fructose was conspicuously lower than that of sucrose during somatic embryogenesis of Acca sellowiana. Glucose and fructose contents showed similar trends, although glucose was always lower than fructose. Glucose is probably preferentially used over fructose to meet metabolic demands (Treat et al., 1989). Low glucose content observed in embryos could be attributed to its utilization as a carbon source for synthesis of sucrose and starch that begin their accumulation at this stage, showing a similar trend to that observed in Norway spruce somatic embryos (Lipavská et al., 2000). One of the known causes of low endogenous hexose content is $\alpha$ amylase synthesis and starch catabolism (Yu et al., 2000), which is a prerequisite for organ formation and somatic embryo differentiation. The reducing glucose and fructose cannot accumulate to high levels without harmful effects, but their great advantage is a more direct entry into metabolism (Lipavská and Konrádova, 2004).

Sucrose is frequently used as a carbon source in plant tissue culture media. Its hydrolysis into glucose and fructose has been demonstrated in a wide variety of plant cell and tissue cultures (George, 1993). In the present experiment, no sucrose content was detected in the media for all treatments, except the control. Akita and Takayama (1994) also reported that in potato microtuber jar fermentar, total sucrose degraded into glucose and fructose after 10 weeks of in vitro growth. Sucrose may have been split into glucose and fructose by exogenous enzymes before uptake (Nùrgaard, 1997). For optimal plantlet growth, sucrose sustainability is necessary and if it is rapidly hydrolyzed into glucose and fructose, it makes the long-term maintenance of desirable sucrose level difficult. Autoclaving contributes to sucrose hydrolysis and also a large amount of it breaks down during growth of plantlets (Kanabus et al., 1986).

\subsection{Chlorogenic acid}

The most abundant phenolic compounds in coffee are hydroxycinnamic acids which exist mainly in the esterified form. An example is chlorogenic acid (5-caffeoylquinic acid) (CGA) which is the most widespread and formed between caffeic and quinic acids (Molgaard and Ravn, 1988). When origin of the leaf node and growth stage were considered, the concentration, nature and localization of CGA varied throughout leaf development with juvenile leaves being the highly accumulating organs (Mondolot et al., 2006). In the present study, fresh leaves had the highest CGA content, similar to analyses of $C$. arabica and C. pseudozanguebariae leaves (Aerts and Baumann, 1994; Bertrand et al., 2003). Sartor and Mazzafera (2000) reported contents of $5.64 \mathrm{mg} / \mathrm{g}$ and $16.78 \mathrm{mg} / \mathrm{g} \mathrm{CGA}$ in C. arabica and C. dewervei, respectively.

Generally, higher CGA resulted in non-embryogenic brown and green leaf discs than in embryogenic brown and green leaf discs, although not significantly different. Similar trend was observed in cocoa where high 
hydroxycinnamic acid was associated with non-embryogenic response (Alemanno et al., 2003). Embryogenic capacity therefore seemed to be associated with balanced concentration of phenolics. When explants are cut, the contents of the cytoplasm and vacuoles mix and come out from the explant and phenolic compounds can readily become oxidized by air. Oxidized phenolic compounds inhibit enzyme activity and result in darkening of the culture medium and subsequent lethal browning of explants or rooting inhibition (Arnaldos et al., 2001; Ozyigit et al., 2007). Residual phenolics are also important in browning and thus the phenolics synthesized by the explants during any period of organogenesis play an important role in browning and rooting problems. The natural rate of formation of some phenolic compounds depends on the rate of growth of cultured tissues (Barz, 1977). In the present study, brown leaf discs had the lowest chlorogenic acid content, implying that explant browning ended in culture growth and competence decline, with eventual loss of totipotency.

Neuenschwander and Baumann (1992) observed embryogenic calli develop only after browning of the initial explant. In some instances, browning of explants did not affect somatic embryo formation. In the present study, somatic embryos also developed after browning of leaf explants. These results demonstrate that somatic embryogenesis induction is not incompatible with phenolic compound production during in vitro culture. Excessive accumulation of phenols that cause browning of the tissues is necessary for the somatic embryogenesis process in coffee (Quiroz-Figueroa et al., 2001). It is possible that these phenolic compounds act as signals to induce the differentiation process. Mucciarelli et al., (2000) reported that phenolic compounds probably act by raising or lowering the level of indole acetic acid through enzymatic reactions.

Khosroushahi et al., (2011) reported a positive correlation between phenolic amounts and callus growth of Taxus brevifolia and this result indicated that phenolics lead to cell proliferation, and thus increase in callus growth instead of secondary metabolite production such as paclitaxel. In addition, an increase of phenolics might facilitate cell wall generation and subsequently enhance cell proliferation (Khosroushahi et al., 2011). Phenolic compounds produced as a response of explants to stress conditions can create a chemical environment appropriate for somatic embryo formation and development. Eldin and Ibrahim (2015) reported that phenols produced during somatic embryogenesis of date palm reacted with hydrogen peroxide produced during IAA degradation, thereby protecting the cell from its toxic effects.

An alternative explanation is that due to the chelating properties of these compounds, some inhibitors present in the embryogenic cultures get inactivated. The results of the present study agreed with a study by Liu et al. (2015) that the Fraxinus mandshurica (1\%) polyphenol was not significantly higher than that in Syringa reticulate var. mandshurica $(0.7 \%)$, but browning of $F$. mandshurica was significantly higher than that of $S$. reticulata var. mandshurica, indicating that the $F$. mandshurica explant browning was not greatly related to accumulation of polyphenols. Liu et al. (2015) predicted that explant browning might be a manifestation of necrosis caused by stress or differential response of explants to the stress, which resulted in a hypersensitivity response that induced PCD and browning of explants. Increase in phenolic content is normally associated with increase in enzymes that regulate synthesis of phenolic compounds, while the intensity of browning is related with the hyperactivity of oxidative enzymes (Cochrane, 1994). Laukkanen et al., (1999) cultured calli from shoot tips of mature Scot pine and examined phenol oxidase development (POD) and activity (PPO). Subsequently, brownish green calli were obtained in 14 days, greenish brown in 28 days and totally brown in 42 days. The PPO activity increased rapidly during culture, but slowed down after 28 days.

The mechanism of action of phenolics is difficult to explain and is somewhat ambiguous; however, it is one factor involved in determining the capacity of plant tissues to regenerate (Cvirková et al., 1999). An increase in phenolic compounds has been associated with a decrease in growth and a decline in protein synthesis. Beruto et al., (1996) observed a higher level of phenols in non-regenerating callus of Ranunculus asiaticus compared to regenerating callus. Hrubcová et al. (1994) and Cvirková et al. (1999) showed that non-embryogenic suspension of Medicago sativa produced more phenolic compounds than embryogenic suspension. It is known that high concentration of caffeine accompanies considerable accumulation of chlorogenic acid to form a complex that store the caffeine in the vacuole (Mösli and Baumann, 1996). It was also observed that during coffee germination, the concentration of chlorogenic acid decreases and caffeine is released, whereas during 
leaf expansion accumulation of both compounds occurs (Aerts and Baumann 1994). Chlorogenic acid could be required to reinforce the cell wall, since together with its derivatives, it is necessary in the lignification process (Aerts and Baumann 1994). This effect is achieved probably through modification of cell plasticity and interference with the embryogenic response (Mounir and Ismail, 2004). Similarly, Eldin and Ibrahim (2015) reported that phenol concentration was at its lowest level in embryogenic callus and then increased during the subsequent developmental stages of date palm somatic embryogenesis. Eldin and Ibrahim (2015) reported gradual increase in the phenol concentrations from 67.8 to $94.7 \mathrm{mg} / 100 \mathrm{~g}$ fresh weight in pro-embryos and mature somatic embryos of date palm somatic embryos and postulated that the high concentration of phenols found in the mature somatic embryos may be used during their conversion to complete plantlets. Abdallah et al., (2001) concluded that large amount of phenols observed in plantlets form the basic material used during subsequent secondary wall formation. These results imply that increase of phenolics facilitates cell wall generation and subsequently enhances cell proliferation (Khosroshahi et al., 2011). Many reports have recommended that the role of phenolic compounds in in vitro cultures should be analyzed more carefully since in some systems, phenols promote in vitro morphogenic processes. It is not yet clear how phenolic compounds affect somatic embryogenesis induction and development. A possible interference of phenolic compounds with auxin metabolism and, as a consequence, with the levels of this plant growth regulator has been suggested (Gross et al., 1977; Pressey, 1990). The study of Ozyigit et al., (2007) indicated that the role of the phenolic compounds depends on its chemical structure, plant species, the biological process studied (organogenesis or somatic embryogenesis), and its developmental stage.

\subsection{Caffeine}

In coffee plants, caffeine is actively biosynthesized during leaflet emergence and then decreases when leaves reach their optimal photosynthetic capacity (Frischknecht et al., 1986). The $1.4 \mathrm{mg} / \mathrm{g} \mathrm{FW}$ and $7.48 \mathrm{mg} / \mathrm{g} \mathrm{DW}$ caffeine obtained in the explant in the present study was in agreement with previous reports. Ashihara et al., (1996) reported that caffeine biosynthesis from adenine and guanine was only found in young leaves, but conversion of theobromine and caffeine was found in mature and aged coffee leaves. Mazzafera et al., (1994) studied metabolism of caffeine in two cultivars of C. arabica, 'Mundo Novo' (commercial cultivar) and 'Laurina' (mutant) and found $8-10 \mathrm{mg} / \mathrm{g}$ and $7 \mathrm{mg} / \mathrm{g}$ caffeine, respectively. Ashihara et al., (1996) found $2.1 \mathrm{mg} / \mathrm{g} \mathrm{FW}$ caffeine in mature leaves, whereas Sartor and Mazzafera (2000) found $9.29 \mathrm{mg} / \mathrm{g}$ DW caffeine in C. arabica. Mazzafera and Magalhães (1991) found $21.9 \mathrm{~g} / \mathrm{kg}$ caffeine in young leaves, which was higher than values reported in literature for C. arabica. However, the result was expected since it has been demonstrated that younger leaves have higher alkaloid content than older leaves (Frischknecht et al., 1986). High endogenous caffeine found in C. arabica leaves may be due to the rate limiting step in purine alkaloid catabolism during the conversion of caffeine to theophylline (Indu, 2004). In a study of caffeine and its metabolites during somatic embryogenesis of $C$. canephora variety CxR, Indu (2004) reported that cotyledonary embryo plantlets formed highest amounts of theobromine and caffeine as compared to callus, globular and torpedo embryos, indicating that caffeine accumulates during embryogenesis. In the present study, high caffeine content in the embryos formed from brown leaf discs was attributed to accumulation during the embryogenesis process.

The ability to produce coffee cell cultures from callus cultures which maintain the ability to produce caffeine and theobromine, and release these purine alkaloids into the medium, has existed for over 40 years most likely due to diffusion (Keller et al., 1972; Waller et al., 1983). Waller et al., (1983) reported that caffeine formation in C. arabica in vitro paralleled tissue growth; however, as the callus grew older, less caffeine remained in the tissue and more was found in the medium. In the present study, the green leaf discs had the least caffeine content and in their embryos and the highest in the medium, agreeing with a previous report by Waller et al., (1983), who found up to $49.9+4.8 \mu$ moles/mg DW caffeine in the culture media.

Nic-Can et al., (2015) studied C. arabica explant secreted compounds and found $11.042 \mu \mathrm{mole} /$ flask and $10.982 \mu \mathrm{mole} /$ flask caffeine in low molecular mass of conditioned medium (LmmCM). The caffeine in media allowed somatic embryos to develop in C. canephora. Similar results have been observed during development of zygotic embryos in coffee (Friedman and Waller, 1983), indicating that the embryos had the ability to avoid 
caffeine autotoxicity through space and time separation. This may be the reason why somatic embryos developed in media with high caffeine content. The mechanism of phenolic action in promoting somatic embryo formation is unclear. It is postulated that there is a factor involved in determining the capacity of plant tissues to regenerate (Cvirková et al., 1999). It is known that high caffeine content is accompanied by accumulation of chlorogenic acid as a pathway to a complex to store the caffeine in the vacuole (Mösli and Baumann, 1996).

\section{CONCLUSION AND RECOMMENDATIONS}

Several biochemicals were identified during development of coffee somatic embryos. Generally, green embryogenic cultures contained higher quantities of the identified biochemicals. Glucose and fructose were highest in brown non-embryogenic cultures. Sucrose was highest in green embryogenic cultures. Since glucose is preferentially used to meet metabolic demand, its decrease was ascribed to its role in the process of embryo growth and development. High endogenous sucrose in the embryo is an indication that embryo maturation is connected with storage matter accumulation. Green embryogenic cultures had the highest chlorogenic acid content, whereas caffeine was highest in brown embryogenic cultures, indicating that high CGA and caffeine in culture media allows development of somatic embryos through space and time separation-avoidance of CGA and caffeine auto-toxicity. Embryogenic capacity seemed to be associated with a balance of phenolics. Other biochemical compounds such as organic acids should be identified and their role in coffee somatic embryogenesis determined.

\section{ACKNOWLEDGEMENTS}

This study was co-financed by the Coffee Research Institute (CRI) and the National Council of Science, Technology and Innovation (NACOSTI) grant reference number NACOSTI/RCD/ST\&I $5^{\text {th }}$ Call PhD/026. The authors thank the technical staff of the Crop Physiology and Chemistry quality Units of CRI for their assistance. This paper is published with the permission of the Institute Director of the CRI on behalf of the Director General, Kenya Agricultural and Livestock Research Organization.

\section{REFERENCES}

1. Abdallah, Y.E.Y., Ibrahim, I.S., Abd-EL-Moniem, E.M., and Youssef, L.A. 2001. Incidence of some piercingsucking insects in relation to morphological leaf characters, some chemical and nutritional components of some cotton cultivars. Annals of Agricultural Sciences 462, 807-827.

2. Aerts, R.J. and Baumann, T.W. 1994. Distribution and utilization of chlorogenic acid in developing coffea seedlings. Journal of Experimental Botany 45, 497-503.

3. Akita, M., and Takayama, S., 1994. Induction and development of potato tubers in a jar fermentar. Plant Cell Tissue and Organ Culture 36, 177-182.

4. Alemanno, L., Ramos, T., Gargadenec, A., Andary, C., and Ferriere, N. 2003. Localization and identification of phenolic compounds in Theobroma cacao L. somatic embryogenesis. Annals of Botany 92, 613-623.

5. Arnaldos, T.L., Munoz, R., Ferrer, M.A., and Calderon, A.A. 2001. Changes in phenol content during strawberry (Fragaria x ananasa), cv. Chandler callus culture. Physiologia Plantarum 113, 315-322.

6. Ashihara, H., Monteiro, A.M. Moritz, T. Gillies, F.M., and Crozier, A. 1996. Catabolism of caffeine and related purine alkaloids in leaves of Coffea arabica L. Planta 198, 334-339.

7. Attree, S. M., Pomeroy, M. K., and Fowke, L. C. 1992. Manipulation of conditions for the culture of somatic embryos of white spruce for improved triacylglycerol biosynthesis and desiccation tolerance. Planta 187, 395-404

8. Barz, W. 1977. Catabolism of endogenous and exogenous compounds by plant cell cultures. In: Barz, W., Reinhard, E. and Zenk, M.H. eds. Plant Tissue Culture and its Biotechnological Application, p. 153-171. Berlin: Springer Verlag.

9. Benson, E.E. 2000. Special symposium: In vitro plant recalcitrance. Do free radicals have a role in plant tissue culture recalcitrance? In Vitro Cell Dev. and Biol.-Plant, 36, 163-170. 
10. Bertrand, C., Noirot, M., Doulbeau, S., De Kochko, A., Hamon, S., and Campa, C. 2003. Chlorogenic acid content swap during fruit maturation in Coffea pseudozanguebaria: Qualitative comparison with leaves. Plant Science 165, 1355-1361.

11. Beruto, M., Cuiri P., and Debergh P. 1996. Callus growth and somatic embryogenesis in thalamus tissue of Ranunculus asiaticus L. cultivated in vitro: cytokinin effect and phenol metabolism. In Vitro Cell. and Dev. Biol. - Plant 32, 154-160.

12. Businge, E., Brackmann, K., Moritz, T, and Egertsdotter, U. 2012. Metabolite profiling reveals clear metabolic changes during somatic embryo development of Norway spruce (Picea abies). Tree Physiol. 32, 232-244.

13. Cochrane, M.P. 1994. Observation on the germ aleurone of barley: Phenol oxidase and peroxidase activity. Annals of Botany 73, 121-128.

14. Cvirková M., Binarová P., Eder J., Vágner M., Hrubcová M., and Zoń J. 1999. Effect of inhibition of phenylanine ammonia-lyase activity on growth of alfalfa cell suspensions culture: Alterations in mitotic index, ethylene production, and contents of phenolics, cytokinins and polyamines, Physiologia Plantarum 107, 329-337.

15. Dijkema, C., De Vries, S. C., Booij, H., Schaafsma, T. J., and Van Kammen, A. 1988. Substrate utilization by suspension cultures and somatic embryos of Daucus carota L. measured by 13C NMR. Plant Physiol. 88, 1332-1337.

16. Eldin, A.F. and Ibrahim, H.A. 2015. Some biochemical changes and activities of antioxidant enzymes in developing date palm somatic and zygotic embryos in vitro. Annals of Agricultural Science 601, 121-130.

17. Filonova, L.H., Bozhkov, P.V., Brukhin, V.B., Daniel, G., Zhivotovsky, B., and Von Arnold, S. 2000. Two waves of programmed cell death occur during formation and development of somatic embryos in the gymnosperm, Norway spruce. Journal of Cell Science 113, 4399-4441.

18. Flinn, B. S., Roberts, D. R., Newton, C.H., Cyr, D. R., Webster F.B., and Taylor, I. E. P. 1993. Storage protein gene expression in zygotic and somatic embryos of interior spruce. Physiologia Plantarum 89, 719-730

19. Friedman, J., and Waller, G. 1983. Caffeine hazards and their prevention in germinating seeds of coffee (Coffea arabica L.). Journal of Chemical Ecology 9, 1099-1106.

20. Frischknecht, P.M., Ulmer-Dufek, J., and Baumann, T.W. 1986. Purine alkaloid formation in buds and developing leaflets of Coffea arabica: Expression of an optimal defense strategy? Phytochemistry 25, 613616

21. George, E.F. 1993. Plant Propagation by Tissue Culture. Part 1: The Technology. Edington, Wilts: Exegetics Limited, p. $322-326$.

22. Gibson, S.I. 2005. Control of plant development and gene expression by sugar signaling. Current Opinion in Plant Biology 8: 93-102

23. Gross, G.G., Janse C., and Elstner, E.F. 1977. Involvement of malate, monophenols, and the superoxide radical in hydrogen peroxide formation by isolated cell walls from horseradish Armoraciala pathifolia Gilib. Planta 136, 271-276.

24. Hrubcová M., Cvirková M., and Eder J., 1994. Peroxidase activities and contents of phenolic acids in embryogenic and non-embryogenic alfalfa cell suspension cultures. Biologia. Plantarum 36, 75-182.

25. Indu, E.P. 2004. Micropropagation of somatic embryogenesis and agrobacterium mediated transformation of Coffea canephora Pierre ex. Froehner. Ph.D. Thesis, University of Mysore. Retrieved from http://ir.cftri.com/149/1/1899_E_P_Indu.pdf.

26. Ivanov, I., Georgiev, V., Berkov S., and Pavlov A. 2012. Alkaloid patterns in Leucojum aestivum shoot culture cultivated at temporary immersion conditions. Journal of Plant Physiology 169, 206-211

27. Jaetzold, R., Schmidt, H., Hornet, Z. B., and Shisanya, C. A. 2007. Farm Management Handbook of Kenya. Natural Conditions and Farm Information. $2^{\text {nd }}$ Edition. Vol. 11/B. Central Kenya. Ministry of Agriculture/GTZ, Nairobi, Kenya.

28. Kanabus, J., Bressan, R.A., and Carpita, N.C. 1986. Carbon assimilation in carrot cells in liquid culture. Plant Physiology 82: 363-368.

29. Kathurima, C.W. and E.K. Njoroge. 2012. Effect of different shade regimes on coffee quality. Proceedings of the $24^{\text {th }}$ International Conference on Coffee Science ASIC held at San Jose, from $11^{\text {th }}$ to $16^{\text {th }}$ November, 2012. 
30. Keller, H., Wanner, H., and Baumann, T.W. 1972. Caffeine synthesis in fruits and tissue culture of Coffea arabica. Planta 108, 338-350.

31. Khosroushahi, A. D., Naderi-Manesh, H., and Simonsen, H. T. 2011. Effect of antioxidants and carbohydrates in callus cultures of Taxus brevifolia: evaluation of browning, callus growth, total phenolics and paclitaxel production. Biolmpacts, 1, 37-45.

32. Laukkanen, H., Häggman, H., Kontunen-Soppela, S., and Hohtola, A. 1999. Tissue browning of in vitro cultures of scots pine: Role of peroxidase and polyphenol oxidase. Physiologia Plantarum 106, 337-343.

33. Lipavská, H., and Konrádová, H. 2004. Somatic embryogenesis in conifers: the role of carbohydrate metabolism. In Vitro Cellular and Development Biology - Plant 40, 23-30.

34. Lipavská, H., Svobodová, H., Albrechtová, J., Kumstyrová, L., Vágner, M., and Vondráková, Z. 2000. Carbohydrate status during somatic embryo maturation in Norway spruce. In Vitro Cellular and Developmental Biology - Plant 36, 260-267.

35. Liu, C., Yang, L., L and Shen, H. 2015. Proteomic analysis of immature Fraxinus mandshurica cotyledon tissues during somatic embryogenesis: Effects of explant browning on somatic embryogenesis. International Journal of Molecular Sciences, 16, 13692-13713.

36. Matthys-Rochon, E. 2005. Secreted molecules and their role in embryo formation in plants: A mini-review. Acta Biologica Cracoviensia series Botanica 47, 23-29

37. Mazzafera, P. and Magalhães, A.C. 1991. Cafeína em folhas e sementes de Coffea e Paracoffea. Revista Brasileira de Botânica, São Paulo, 14, 157-160.

38. Mazzafera, P., Wingsle, G., Olsson, O., and Sandberg, G. 1994. S-adenosylmethionine: Theobromine 1-Nmethyltransferase an enzyme catalysing the synthesis of caffeine in coffee. Phytochemistry 3, 1577-1584.

39. Molgaard, P., and Ravn, A. 1988. Evolutionary aspects of caffeoyl ester distribution in dicotyledonous. Phytochemistry 27, 2411-2421.

40. Mondolot, L., La Fisca, P., Buatois, B., Talansier, E., De Kochko, A., and Campa, C. 2006. Caffeoylquinic acid content and histolocalization in Coffea canephora developing leaves. Annals of Botany 98, 33-40.

41. Mösli, W.S., and Baumann, T.W. 1996. Compartmentation of caffeine and related purine alkaloids depends exclusively on the physical chemistry of their vacuolar complex formation with chlorogenic acids. Phytochemistry 42, 985-996.

42. Mounir, E.B. and Ismail, E.H. 2004. Characterization of two non-constitutive hydroxycinnamic acid derivatives in date palm Phoenix dactylifera L. callus in relation with tissue browning. Biotechnology 3: 155159. pmid: 15292581

43. Mucciarelli, M.S., Scannerini, M. Gallino., andMaffei, M. 2000. Effect of 3,4-dihydroxybenzoic acid on tobacco Nicotiana tabacum L. cultured in vitro. Growth regulation in callus and organ culture. Plant Biosystems. 134(2), 185-192.

44. Navarro, B. V., Elbl, P., De Souza, A. P., Jardim, V., de Oliveira, L. F., Macedo, A. F., Floh, E. I. S. 2017. Carbohydrate-mediated responses during zygotic and early somatic embryogenesis in the endangered conifer, Araucaria angustifolia. PLOS ONE, 127.

45. Neuenschwander, B., and Baumann, T.W. 1992. A novel type of somatic embryogenesis in Coffea arabica. Plant Cell Reports. 10, 608-612.

46. Nic-Can, G. I., Galaz-Ávalos, R. M., De-la-Peña, C., Alcazar-Magaña, A., and Loyola-Vargas V. M. 2015. Somatic embryogenesis: Identified factors that lead to embryogenic repression. A case of species of the same genus PLOS ONE 106.

47. Nùrgaard, J.V. 1997. Somatic embryo maturation and plant regeneration in Abies nordmandiana Lk. Plant Science 124, 211-221.

48. Osborne, D. R., and Voogt, P. 1978. The analysis of nutrients of food. London: Academic Press.

49. Ozyigit, I.I., Kahraman, M.V., and Ercan, O. 2007. Relation between explant age, total phenols and regeneration response of tissue cultured cotton Gossypium hirsutum L.. African Journal of Biotechnology $61,3-8$.

50. Pescador, R., Kerbauy, G. B., Kraus, J. E., Ferreira, W. M., Guerra, M. P.., and Figueiredo-Ribeiro, R. C. L. 2008. Changes in soluble carbohydrates and starch amounts during somatic and zygotic embryogenesis of Acca sellowiana Myrtaceae. In Vitro Cellular and Developmental Biology - Plant 444, 289-299. 
51. Pressey, R. 1990. Anions activate the oxidation of indole acetic acid by peroxidases from tomato and other sources. Plant Physiology. 93, 798-804.

52. Quiroz-Figueroa, F.R., Méndez-Zeel, M., Larqué-Saavedra, A. and Loyola-Vargas, V.M. 2001. Picomolar concentrations of salycilates induced cellular growth and enhanced somatic embryogenesis in Coffea arabica tissue culture. Plant Cell Reports 20, 679-684.

53. Sánchez-Romero, C., Perán-Quesada, R., Barceló-Muñoz, A., Fernando Pliego-Alfaro, F. 2002. Variations in storage protein and carbohydrate levels during development of avocado zygotic embryos. Plant Physiology and Biochemistry 40, 1043-1049.

54. Sartor, R.M., and Mazzafera, P. 2000. Caffeine formation by suspension cultures of Coffea dewevrei. Brazilian Archives of Biology and Technology, 431.

55. Strum, A., and Tang, G. 1999. The sucrose-cleaving enzymes of plants are crucial for development, growth and carbon partitioning. Trends in Plant Science 410, 401-407.

56. Treat, W.J., Engler, C.R. and Soltes, E.J. 1989. Culture of photomixotropic soybean and pine in modified fermentor using a novel impeller. Biotechnology and Bioengineering 34, 1191-1202.

57. Tremblay, L. and Tremblay, F. M. 1991. Carbohydrate requirements for the development of black spruce Picea mariana Mill. and red spruce P. rubens Sarg. somatic embryos. Plant Cell, Tissue and Organ Culture. 27, 95-103.

58. Waller, G. R., MacVean, C. D. and Suzuki, T. 1983. High production of caffeine and related enzyme activities in callus cultures of Coffea arabica L. Plant Cell Reports 2, 109-112.

59. Yu, W.C., Joyce, P.J., Cameron, D.C. and McCown, B.H. 2000. Sucrose utilization during potato microtuber growth in bioreactors. Plant Cell Reports 19, 407-413.

\section{Conflicts of Interest}

The authors declare that there is no conflict of interest regarding the publication of this article.

\section{Authors' Biographies with Photos}

Dr. Rose N. Mayoli was born in 1978 in Machakos-Kenya, and received both her B.Sc. in Horticulture in 2003 and M.Sc. in 2008 from Egerton University, Kenya and Ph.D. in Plant Biotechnology in 2018 from Chuka University, Kenya. Dr. Mayoli's work experience has included: July 2003-August 2003 Quality Controller, Equator Flowers Kenya Limited, August 2003-August 2004 Assistant Production Manager, Carzan Flowers Kenya Limited; January 2009-July 2009 Senior Quality Control Supervisor, Primarosa Flowers Kenya Limited; September 2009-date, Research Officer and Head of Plant Physiology Unit, Coffee Research Institute, Kenya Agricultural and Livestock Research Organization. Dr. Mayoli's research interests concern horticulture, floriculture, beverage crops, plant growth regulators, plant tissue culture, plant biotechnology, molecular biology, and plant physiology.

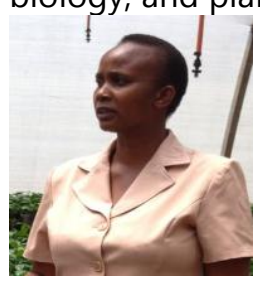

Prof. Dorcas K. Isutsa was born in 1966 in Kakamega and has earned the following: 2004-2005 Academic \& Research Fellow Certificate, University of Reading, UK, 26 Apr-2 July 2004 Plant Biotechnology, Biosafety \& Biotechnology Certificate, Wageningen International Agricultural Centre, Netherlands; 1994-1998 Ph.D. in Horticulture, 1991-1993 M.Sc. in Pomology both from Cornell University, USA, and 1987-1990 a B.Sc. in Horticulture, Egerton University, Kenya. Prof. Isutsa has held the following administrative positions: from $11^{\text {th }}$ Sept. 2013-date, Deputy Vice-Chancellor (Academic, Research \& Student Affairs); Jan-Aug. 2013, Ag. Deputy Vice-Chancellor (Academic Affairs) of Chuka University; Mar. 2011-Jan. 2013, Deputy Principal, Chuka University College. Prof. Isutsa has worked in professional positions as follows: $15^{\text {th }}$ Sep. 2013-date, Full Professor; October 2003-Sep. 2013, Associate Professor; June 1999-Sep. 2003, Senior Lecturer; Feb. 1997-May 
1999, Lecturer; June 1993-1997, Assistant Lecturer; Oct. 1990-May 1993, Teaching Assistant, all at Egerton University, Njoro; 1994-1998, Research Assistant, and parts of 1991-1998, Teaching Assistant, Cornell University, USA. Prof. Isutsa's research interests include fruit sciences, plant nursery and orchard management, plant biotechnology, and horticulture.

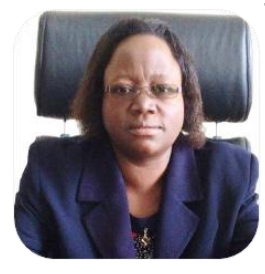

Prof. Aggrey B. Nyende was born in 1966 in Kakamega, Kenya and pursued University education as follows: 1986-1989 B.Sc. (Agriculture); 1989-1991 M.Sc. (Plant Breeding and Genetics) both from University of Nairobi (Kenya); 2000-2003 Doctorate (Agricultural Science) Kiel University (Germany); Prof. Aggrey B. Nyende's worked as follows: 1985-1986, Civil servant: Cartography Department. Ministry of Finance and Economy; 19901991, Research Assistant: Pigeon pea Improvement Project-Crop Science Department, University of Nairobi; 1993, Energy Conservation Officer: Eukawa Technical Services, Kiambu; 1994-1999, Self-employed: Agricultural consultation services to flower and horticultural farmers in Kenya; 1994-1999 (2005), Lecturer (Part-time): Horticulture/Botany departments, Jomo Kenyatta University for Agriculture and Technology (JKUAT); 20002003, Research Fellow: Institute for Crops and Grassland Sciences, Federal Agricultural Research Centre, Braunschweig, Germany; 2005, Netherlands Scholarship Fellow: Plant breeding and Biotechnology training; 2006 to 2008, Lecturer: Horticulture Department-JKUAT; 2008 to 2012, Senior Lecturer, Horticulture Department; 2013-date, Associate Professor, JKUAT; 2008-2011, In-Country Co-supervisor: University of Kwazulu-Natal; 2008-date, Director, Institute for Biotechnology Research (JKUAT) for biotechnology and tissue culture research and development, training in biotechnology at postgraduate level, and supporting structure for biotechnology research innovations and products. Prof. Nyende's research interests are in molecular biology, plant breeding and tissue culture.

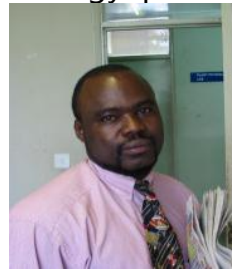

Dr. Cecilia Mbithe Mweu was born in 1975 in Machakos, Kenya. Dr. Mweu's academic background includes 2008-2012 PhD. (Biotechnology), JKUAT, Kenya; 2005-2006 Development Oriented Plant Biotechnology and Biosafety, Germany; 2002-2004 M.Sc. (Natural Products and Biotechnology), MAICH, Greece; 2001-2002 Post graduate Diploma (Natural Products and Biotechnology), MAICH, Greece; 1996-2000: B.Sc. (Botany and Zoology), University of Nairobi, Kenya. From 2004-2007, she worked as a Research Scientist, Department of Molecular Genetics, National Museums of Kenya. Presently, Dr. Mweu is a researcher/lecturer at the Institute of Biotechnology Research of Jomo Kenyatta University of Agriculture and Technology, Kenya. Dr. Mweu's research interests include molecular biology, tissue culture, phytochemistry and genetic engineering.

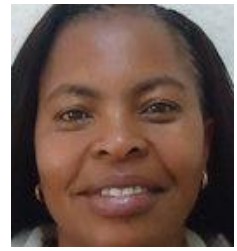

